\title{
A MODEL TO DETERMINE RELIEF WAREHOUSE LOCATION IN EAST JAKARTA USING THE ANALYTIC HIERARCHY PROCESS
}

\author{
Rega Tadeak Hakim ${ }^{1}$, Ratih Dyah Kusumastuti ${ }^{1 *}$ \\ ${ }^{1}$ Department of Management, Faculty of Economics and Business, Universitas Indonesia, Kampus \\ UI Depok, Depok 16424, Indonesia
}

(Received: February 2018 / Revised: February 2018 / Accepted: August 2018)

\begin{abstract}
Relief logistics plays a critical role in the success of disaster relief operations. One way to improve the smoothness of such activities is the strategic placement of storage facilities to ensure that relief aid reaches disaster victims in a short space of time. This paper presents a decision-making model to determine the location of relief warehouses using the Analytic Hierarchy Process (AHP). We first identify a set of criteria to be considered in the model by reviewing the literature and conducting in-depth interviews (IDIs) with representatives from the Regional Agency for Disaster Management (BPBD) and The Indonesia Red Cross (PMI) in Jakarta. We then develop the AHP model with first-level criteria, namely costs, geographic location, infrastructure, proximity, and the macro-environment, and consider three alternative locations (Cipinang Besar Utara, Cipinang Besar Selatan, and Pondok Kelapa) for a relief warehouse to serve victims of floods in East Jakarta. The pairwise comparisons are conducted by five experts, and the results show that geographic location has the highest weight, while cost has the lowest, with Cipinang Besar Utara chosen as the preferred location.
\end{abstract}

Keywords: Analytic Hierarchy Process; Location selection criteria; Relief logistics; Warehouse

\section{INTRODUCTION}

Indonesia is very prone to disasters. According to the United Nations Office for Disaster Risk Reduction (UNISDR), with regard to disaster risk, Indonesia is ranked 67 among 191 countries in the world (UNISDR, 2017). In 2017 alone (up until August), the number of disasters in the country was 1601 , events which caused the loss of 295 people, with 2.1 million displaced from their homes (BNPB, 2017a). Concerning the type of disaster, floods occurred 575 times in 2017 alone (BNPB, 2017a). In Jakarta (the capital city of Indonesia) in particular, floods occurred 98 times in the period 2011-2015 (BNPB, 2017b).

UNISDR (2009) defines a disaster as:

"a serious disruption of the functioning of a community or a society at any scale due to hazardous events interacting with conditions of exposure, vulnerability, and capacity, leading to one or more of the following: human, material, economic and environmental losses and impacts."

Based on the above definition, one way to reduce disaster risk is to increase the capacity to manage disaster and improve resilience, which may include infrastructure, institutions, human

\footnotetext{
*Corresponding author's email: ratih.dyah@ui.ac.id, Tel. +62-21-7272425, Fax. +62-21-7270024 Permalink/DOI: https://doi.org/10.14716/ijtech.v9i7.1596
} 
knowledge and skills, and collective attributes such as social relationships, leadership, and management (UNISDR, 2009).

The logistics infrastructure plays a vital role in increasing the capacity that leads to improved resilience against disaster (Kusumastuti et al., 2014). Effective logistics management is one of the critical success factors in disaster management (Moe \& Pathranakul, 2006). The objective of relief/emergency logistics is to transport appropriate emergency supplies promptly to those affected by disasters in order to minimize human suffering and death (Balcik et al., 2008). Relief logistics is an important issue, as it accounts for eight percent of the total relief or humanitarian operations (Van Wassenhove, 2006).

Relief/emergency logistics covers various activities and issues, such as evacuation, stock prepositioning, facility location, relief distribution and casualty transportation (Roh et al., 2015). The role of warehouse pre-positioning in disaster management aims to increase the capacity to deliver sufficient relief aid within a relatively short timeframe and to provide shelter and assistance to disaster victims (Caunhye et al., 2012), thus saving human lives and minimizing suffering.

Previous research related to the determination of warehouse locations has been conducted both in the context of commercial and humanitarian supply chains. Ko (2005) and Ashrafzadeh et al. (2012), for instance, proposed a decision-making model to decide the best location for commercial warehouses, using the analytic hierarchy process (AHP) and fuzzy-AHP respectively. Ko (2005) proposed five decision criteria (population status, transportation conditions, market environments, location properties, and cost-related factors) and 20 subcriteria, while Ashrafzadeh et al. (2012) proposed seven criteria (costs, labor characteristics, geographical location, infrastructure, market, macro environment, and economic factors) and 20 sub-criteria.

In the context of relief/humanitarian logistics, previous studies have proposed approaches to the selection of warehouse location for relief/humanitarian operations; for instance, studies by Turgut et al. (2011), Roh et al. (2013), Roh et al. (2015), Caunhye et al. (2016), and Maharjan and Hanaoka (2017). Turgut et al. (2011) used fuzzy-AHP to select a disaster logistics center in Istanbul, with the criteria (cost, transportation, infrastructure, geographic location and suitability of climate) and 11 sub-criteria obtained from disaster practitioners. Roh et al. (2013) investigated the criteria that had been used to select regional warehouse location in humanitarian relief operations by conducting a small-scale survey. They identified five criteria, namely location, logistics, national stability, cost and cooperation, and 25 sub-criteria. Roh et al. (2015), on the other hand, used a combination of AHP with fuzzy-TOPSIS to determine warehouse pre-positioning for a humanitarian relief organization. AHP was used to determine the criteria weights, while fuzzy-TOPSIS was used in evaluating the alternative locations. Besides the AHP-based approach, mathematical programming has also been used for warehouse location decision-making. Caunhye et al. (2016) proposed a two-stage locationrouting model with recourse to integrated preparedness and response planning under uncertainty. In the first stage, the model set up warehouses and determined their emergency supply inventory level, while in the second stage the model planned trans-shipment quantities, delivery quantities, and vehicle routes for each scenario of uncertainty realization. Maharjan and Hanaoka (2017) used a modified version of the maximal-covering problem to determine the optimal number and location of warehouses to be situated in Nepal for the humanitarian relief chain, which would respond to sudden-onset disasters. Further emergency facility location selection using optimization models is discussed by Boonmee et al. (2017).

Several studies have discussed relief warehouse location selection in the context of Indonesia. Kusumastuti et al. (2013) proposed hierarchical models to determine temporary relief logistics 
facility locations during the disaster response stage, with a case study of the 2007 flood in the East Jakarta district. The first model was used to determine facility locations at the urban village level, while the second was used to select such locations at the district level. Both models were developed using mathematical programming. Handayani et al. (2015), on the other hand, developed a model to determine warehouse pre-positioning for the Mount Merapi eruption in Yogyakarta province. They used a combination of AHP and fuzzy-Topsis, whereby AHP was used to determine the weights of the criteria and sub-criteria, while fuzzy-Topsis was used to determine warehouse location. They identified seven criteria (location, national stability, cost, cooperation, access to logistics, safety and warehouse facilities), and 24 subcriteria. Finally, Timperio et al. (2018) presented a decision model for warehouse prepositioning (for emergency stockpiles) selection in West Sumatra province. They identified eight criteria (coverage, access to affected zones, risk, access to infrastructure, access to corridor, congestion, costs, and national development plan), and used fuzzy-AHP to select the location out of six alternatives.

Even though models for relief warehouse location decision-making have been developed, a different type of disaster and different conditions in the disaster area may require different decision-making models. Therefore, this research aims to develop such a model to determine the best location for a relief warehouse in East Jakarta district for pre-positioned relief materials, related to the frequent flood events in the area. East Jakarta district experienced a severe flood in 2014. According to the data from BPBD Jakarta, the number of affected residents in the district during this flood was around 89,000, with about 32,000 people evacuated from their homes. In the area of Kampung Melayu and Bidara Cina in particular, the water level reached 7 meters, because both areas are located on the Ciliwung riverbank (BNPB, 2014).

The model is developed using AHP, as this is very practical and allows multiple criteria to be taken into account in the decision making, and thus fits with the problem of determining warehouse location for relief supplies. Hence, this paper contributes to disaster preparedness in Indonesia, especially in East Jakarta, by providing a decision-making model for relief warehouse location, as well as insights into the decision criteria that are considered as important by representatives of the institutions that are usually involved in responding to floods in the area.

The remainder of the paper is structured as follows. The research methodology is presented in Section 2, which is followed by explanations of the results and discussion in Section 3, and the conclusion in Section 4.

\section{METHODS}

As previously mentioned, the decision-making model was developed using AHP. According to Saaty (2008), Lee et al. (2008) and Turgut et al. (2011), the process can be summarized as:

- Step 1: Defining the problem and determining the goal.

- Step 2: Identifying the decision criteria, sub-criteria and alternatives, and structuring them into a decision-making model (see Figure 1).

- Step 3: Developing pairwise comparison matrices (the nine-scale pairwise comparison is presented in Table 1) and calculating the eigenvalue and eigenvector, and the consistency ratio of each pairwise comparison. The pairwise comparison matrix with $n$ criteria is an $n \times n$ square matrix $A$, whose element $a_{i j}$ is the value of the comparison of $i^{\text {th }}$ over $j^{\text {th }}$ criteria, while the value of reverse comparison is denoted by $1 / a_{i j}$. Matrix $W$ is then constructed by dividing each column of matrix $A$ by its column sum. The principle eigenvalue of the matrix $\left(\lambda_{\max }\right)$ is then calculated using the following equation: 


$$
A W=\lambda_{\max } W
$$

The consistency ratio $(C R)$ of each pairwise comparison is then calculated as:

$$
\begin{aligned}
& C R=\frac{C I}{R I} \\
& C I=\frac{\lambda_{\max }-n}{n-1}
\end{aligned}
$$

where $C I$ is the consistency index and $R I$ is the random index (see Table 2). The comparison is considered to have satisfactory consistency if $\mathrm{CR} \leq 0.1$.

- Step 4: The best alternative is determined using the weights of the eigenvector.

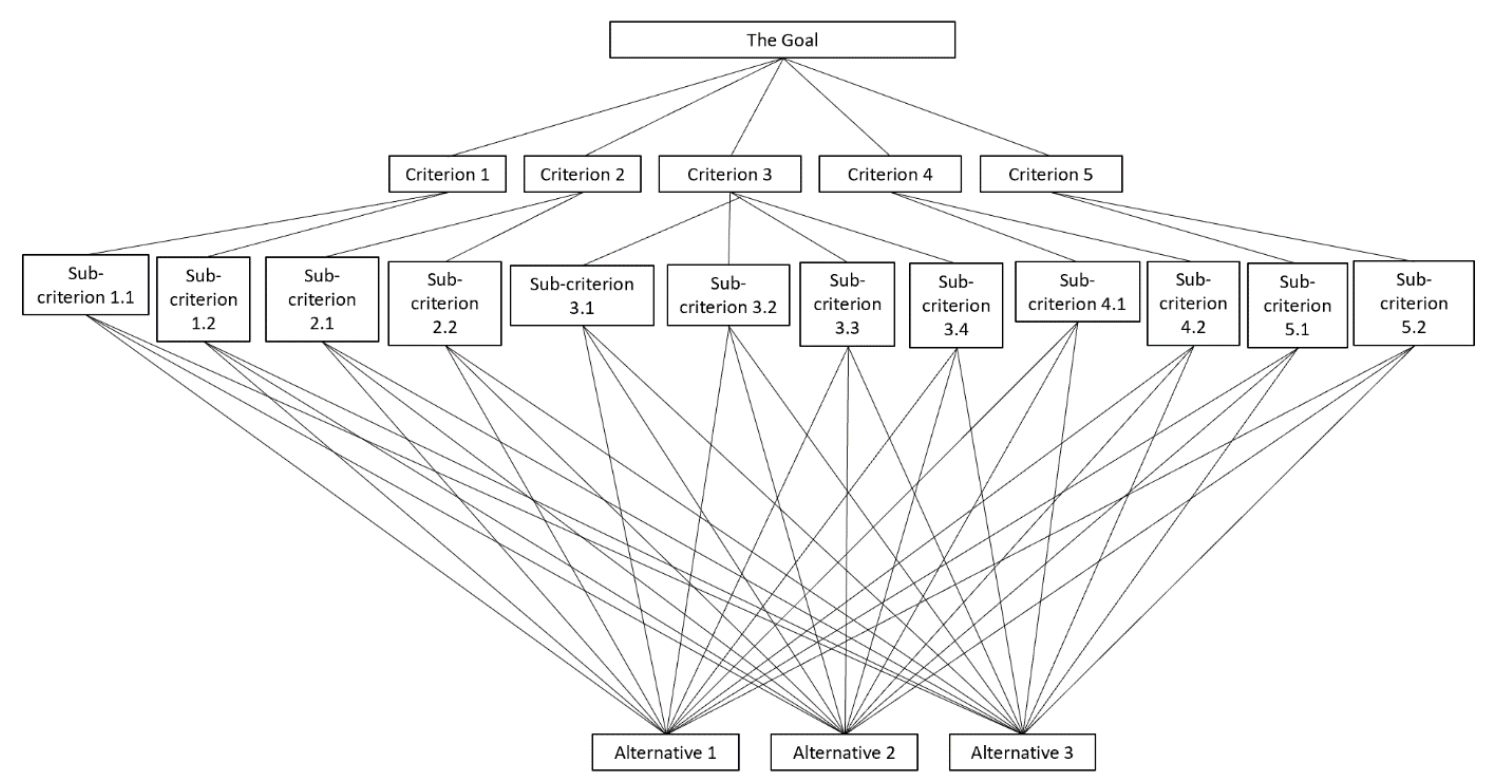

Figure 1 Hierarchical structure

Table 1 Importance scale of pairwise comparisons

\begin{tabular}{cll}
\hline $\begin{array}{c}\text { Intensity of } \\
\text { importance }\end{array}$ & \multicolumn{1}{c}{ Definition } & \multicolumn{1}{c}{ Explanation } \\
\hline 1 & Equal importance & Two activities contribute equally to the objective \\
\hline 3 & Moderate importance & $\begin{array}{l}\text { Experience and judgement slightly favor one } \\
\text { activity over another }\end{array}$ \\
\hline 5 & Strong importance & $\begin{array}{l}\text { Experience and judgement strongly favor one } \\
\text { activity over another }\end{array}$ \\
\hline 7 & Very strong importance & An activity is favored very strongly over another \\
\hline 9 & Extreme importance & $\begin{array}{l}\text { The evidence favoring one activity over another is } \\
\text { of the highest possible order of affirmation }\end{array}$ \\
\hline $2,4,6,8$ & $\begin{array}{l}\text { Intermediate values between } \\
\text { adjacent scale values }\end{array}$ & \\
\hline
\end{tabular}

Table 2 Random index

\begin{tabular}{lcccccccccc}
\hline Matrix Index & 1 & 2 & 3 & 4 & 5 & 6 & 7 & 8 & 9 & 10 \\
\hline RI Value & 0 & 0 & 0.52 & 0.89 & 1.11 & 1.25 & 1.35 & 1.40 & 1.45 & 1.49 \\
\hline
\end{tabular}

In this research, in order to identify the criteria that will be used to select the best relief warehouse location, we first conduct a literature review. The identified criteria are then discussed with experts in the area, through in-depth interviews (IDIs) with three representatives 
from institutions that are usually involved in relief/humanitarian activities in Jakarta. These experts were the Head of Section of Disaster Logistics of the Regional Body for Disaster Management Jakarta (BPBD Jakarta), the Head of Department of Disaster Services of the Jakarta Red Cross (PMI Jakarta), and the Head of Sub-Division of General Affairs of the East Jakarta Red Cross (PMI Jakarta Timur). This process was intended to ensure that the chosen criteria and sub-criteria were relevant to the case of selecting the best relief warehouse location in the East Jakarta district.

The potential locations (alternatives) for the relief warehouse were also determined based on the recommendations from the experts and secondary data obtained from the institutions. The resulting criteria and alternatives (potential warehouse locations) were then structured as a decision-making model. Thereafter, pairwise comparisons were conducted by five experts; the three abovementioned experts, together with the Head of Department of Logistics of PMI Headquarters and the Head of Department of Emergency Response of PMI Jakarta. The weights of all the criteria, sub-criteria and alternatives were then obtained by using the Expert Choice software.

\section{RESULTS AND DISCUSSION}

\subsection{Result}

\subsubsection{Step 1}

In Step 1, we define the problem and formulate the goal. The problem in this case is the need to have a relief warehouse in the East Jakarta district to anticipate flooding, which frequently occurs in the area. Thus, the goal is to determine the best location for a relief warehouse in East Jakarta.

\subsubsection{Step 2}

In Step 2, we determine the criteria and sub-criteria for the decision-making model. Determination of the location of the relief warehouse in the East Jakarta district can be considered to be a complex problem, because it must take into account the potential area affected by floods, proximity to the relief aid donor locations, and land availability in the area. Based on the literature review and IDIs with the representatives from institutions that are usually involved in relief/humanitarian operations, we identified five selection criteria, namely costs, geographic location, infrastructure, proximity and the macro-environment, together with a total of twelve sub-criteria. The identified criteria and sub-criteria from the literature, combined with the criteria suggested by the experts, are presented in Table 3.

Table 3 Criteria and sub-criteria

\begin{tabular}{lll}
\hline \multicolumn{1}{c}{ Criterion } & \multicolumn{1}{c}{ Sub-criterion } & \multicolumn{1}{c}{ Sources } \\
\hline \multirow{2}{*}{ Costs } & Transportation cost & Ashrafzadeh et al. (2012) \\
\cline { 2 - 3 } Geographic Location & Land cost & Ko (2005) \\
\cline { 2 - 3 } & Located in a disaster-safe area & IDIs \\
\cline { 2 - 3 } Infrastructure & Land availability & Ko (2005) \\
\cline { 2 - 3 } & Public transportation & Ko (2005) \\
\cline { 2 - 3 } & Access to airport and seaport & IDIs \\
\cline { 2 - 3 } Poad access & Utilities & IDIs \\
\hline \multirow{2}{*}{ Proximity } & To the affected area & Turgut et al. (2011) \\
\cline { 2 - 3 } Macro-environmet al. (2011) & To the relief aid entry points & Ashrafzadeh et al. (2012) \\
\hline
\end{tabular}


The cost criterion includes the transportation costs to deliver relief supplies to the affected area and the land/building purchasing/leasing costs. The geographic location criterion is defined as the condition of the potential location, i.e. whether it is located in a disaster-safe area and whether the available land is sufficient for the warehouse (including parking space and the possibility for facility extension). The infrastructure criterion covers aspects such as the availability of public transportation, access to airports and seaports, access to main roads, as well as utilities (clean water, electricity and telecommunications network). The proximity criterion, on the other hand, is determined by considering the distances between potential locations and the affected area, and between the potential locations and the entry point of relief supplies. Finally, the macro-environment criterion includes the security of the area from criminal activities and potential conflicts, and its development plan.

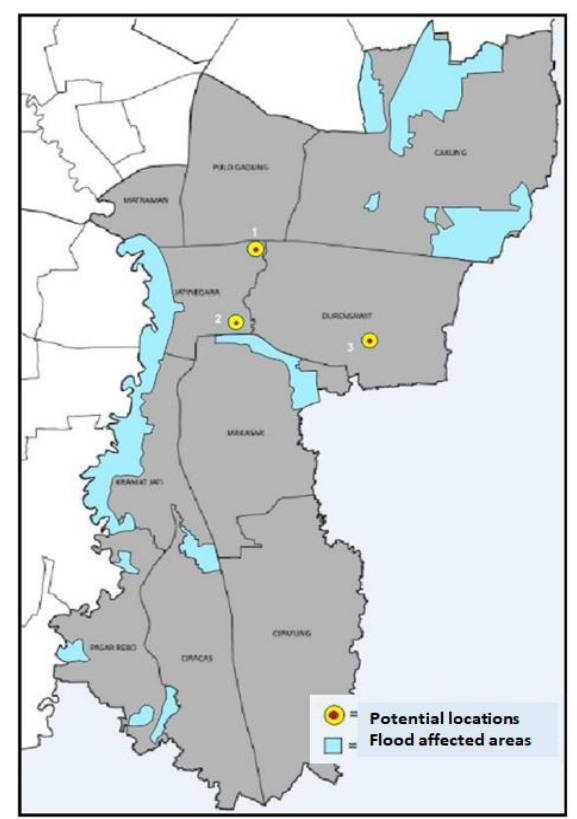

Figure 2 Potential locations for the relief warehouse, and flood-affected areas

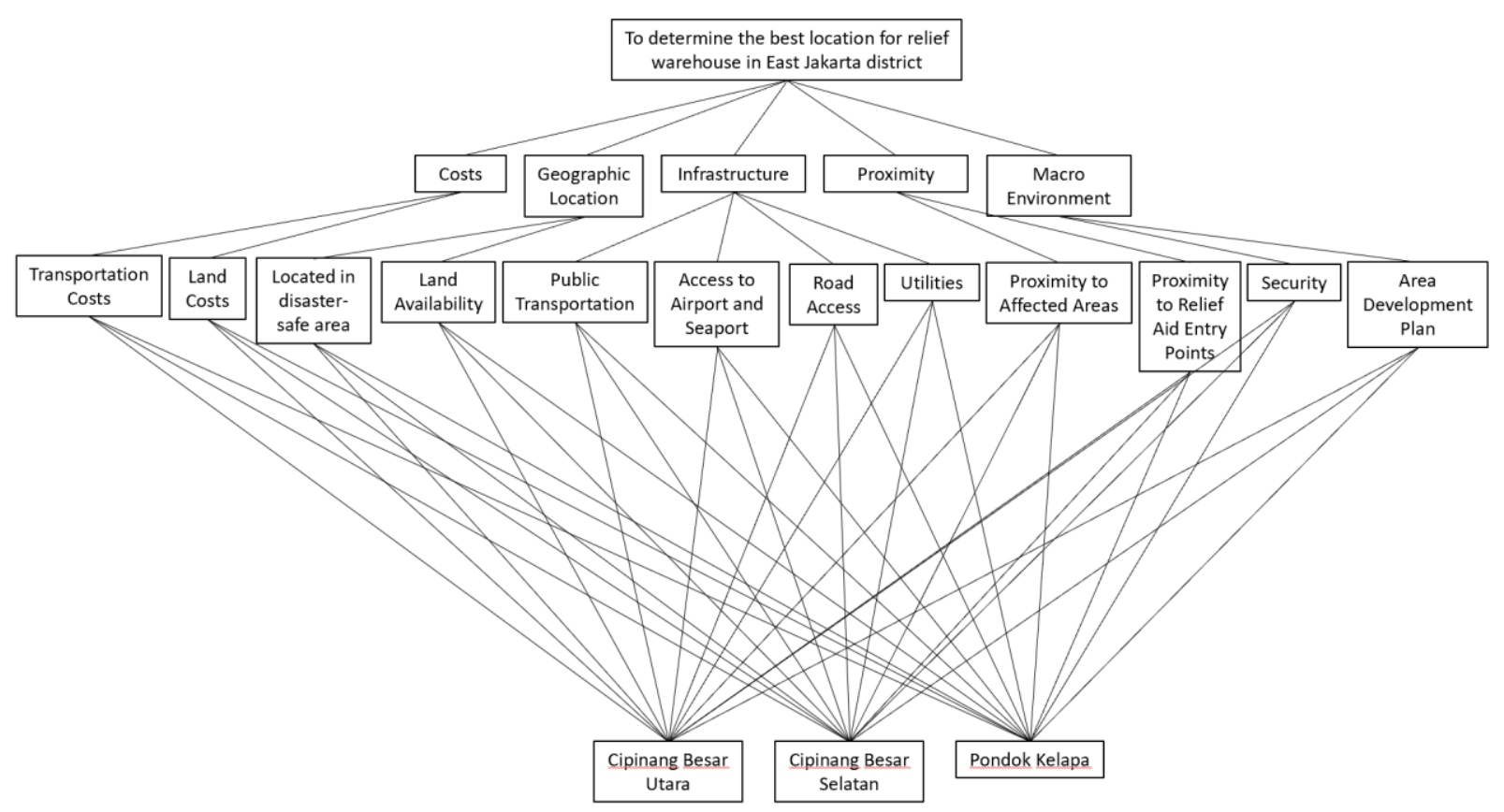

Figure 3 Decision-making model 
The potential locations for the relief warehouse were determined by considering the land availability and geographic location of the sites; i.e., whether they could cover the potential area in East Jakarta district affected by floods, and whether they were located in a flood-free area. The selection process was also conducted by taking into account the experts' opinions and experiences in handling floods in East Jakarta, as well as considering the areas which suffer the most during floods, namely the Jatinegara, Makasar and Kramat Jati sub-districts. The three alternative locations for the relief warehouse were Cipinang Besar Utara and Cipinang Besar Selatan (located in Jatinegara sub-district), and Pondok Kelapa (located in Duren Sawit subdistrict), see Figure 2. The criteria, sub-criteria and alternatives were then structured, with the resulting decision-making model presented in Figure 3.

\subsubsection{Step 3}

As previously mentioned, we asked five experts to make nine-scale pairwise comparisons of the level of importance of the criteria, sub-criteria and alternatives. The consistency ratios of all the pairwise comparisons made by the experts for all the criteria, sub-criteria and alternatives were in the range 0.06 to 0.09 . These figures are below the limit of 0.1 , and thus it can be concluded that all the pairwise comparisons are consistent. The resulting weights for all the criteria, subcriteria and alternatives are presented in Table 4.

Table 4 Resulting weights

\begin{tabular}{lllc}
\hline \multicolumn{1}{c}{ Criterion } & \multicolumn{1}{c}{ Sub-criterion } & Alternatives & Weight \\
\hline Costs & & & 0.054 \\
Geographic Location & & & 0.319 \\
Infrastructure & & & 0.282 \\
Proximity & & & 0.195 \\
Macro-environment & & & 0.150 \\
\hline \multirow{2}{*}{ Costs } & Transportation costs & 0.741 \\
& Land costs & & 0.259 \\
\hline \multirow{2}{*}{ Geographic Location } & Located in a disaster-safe area & & 0.718 \\
& Land availability & & 0.282 \\
\hline \multirow{4}{*}{ Infrastructure } & Public transportation & & 0.077 \\
& Access to airport and seaport & & 0.216 \\
& Road access & 0.499 \\
\multirow{2}{*}{ Proximity } & Utilities & & 0.208 \\
\hline \multirow{2}{*}{ Macro-environment } & To the affected area & 0.562 \\
& To the relief aid entry points & & 0.438 \\
\hline \multirow{2}{*}{} & Security & & 0.553 \\
& Area development plan & Cipinang Besar Utara & 0.447 \\
\hline & & Cipinang Besar Selatan & 0.397 \\
& & Pondok Kelapa & 0.349 \\
& & & 0.254 \\
\hline
\end{tabular}

\subsubsection{Step 4}

Based on the resulting weights of the alternatives in Table 4, Cipinang Besar Utara was chosen as the best location for the relief warehouse in East Jakarta district.

\subsection{Discussion}

It can be seen from Table 4 that the experts considered that the most important criterion in the warehouse location selection process was geographic location, followed by infrastructure, proximity, macro-environment and costs. This result suggests that in setting up the relief warehouse, aspects such as whether the potential sites were located in a disaster-safe zone, the availability of infrastructure and easy access to the area were very important considerations. 
Costs, on the other hand, were not considered to be a big issue, which is consistent with the main objective of relief logistics, namely to deliver relief aid to disaster victims as soon as possible in order to minimize human loss and suffering.

In terms of the costs criterion, the results show that the experts thought that minimizing transportation costs during relief/humanitarian operations had a higher priority than initial warehouse land costs. In the case of the geographic location criterion, the experts believed that it was more important that the warehouse was located in a disaster-free zone than the question of land availability (whether the potential sites had sufficient parking space and the possibility of facility extension). This is because facility location is considered to be a long-term decision, so it is important to ensure that the location will not be impacted by floods.

Regarding the infrastructure criterion, the results indicate that access to a main road is very important in selecting the warehouse location. Moreover, relief operations seldom use public transportation, and so this is considered less important than the availability of utilities and access to airports and seaports.

Concerning the proximity criterion, a close distance to the flood-affected area is considered more important than proximity to the relief aid entry points, which is to ensure that relief supplies can reach the affected people in the shortest amount of time. Lastly, with regard to the macro-environment criterion, the experts considered that ensuring that the warehouse was located in a secure area was more important than the development plan for the area. This suggests that the security of the area is very important, as it ensures that relief supplies will be securely stored.

Regarding the alternatives for the relief warehouse, the results show that the potential sites in Cipinang Besar Utara and Cipinang Besar Selatan were preferable to the site in Pondok Kelapa. The first two sites are located in Jatinegara sub-district, the area which suffered the most in the last flood in East Jakarta district. Hence, the combination of proximity and accessibility mean both sites in Jatinegara sub-district have higher weights than the Pondok Kelapa site. Cipinang Besar Utara, in particular, has the highest weight because it has more land available and its environment is considered to be safer than the other two sites.

\section{CONCLUSION}

Logistics infrastructure is one of the most important factors that determines the success of relief/humanitarian operations during and after disaster events. The paper has presented a decision-making model to determine the best location for a relief warehouse in East Jakarta district to respond to the floods that frequently occur in the area.

Based on the literature review and the results of the IDIs with the representatives from the institutions that are usually involved in disaster management in the area, we identified five criteria, namely costs, geographic location, infrastructure, proximity and macro-environment, and a total of twelve sub-criteria. Based on the IDI results and analysis of the secondary data, we also determined three alternative locations for the warehouse, in Cipinang Besar Utara, Cipinang Besar Selatan and Pondok Kelapa.

The results show that locating the warehouse in a disaster-free zone has the highest priority in the process and that the cost criterion is not considered to be an issue, as the objective of relief logistics is to minimize human suffering and loss. The results show that the site in Cipinang Besar Utara was selected as the preferred location for the relief warehouse, as it is close to the potential area affected by floods, it has more land availability, and it is considered to be safer than the other two sites. 
The decision-making model developed in this research has limitations. First, the alternatives for relief warehouse location were solely determined by the experts. In cases when the number of alternatives is high, the decision-making model can be modified by adding a sub-model to select the best three or five from all the alternatives. Second, the experts in this research were from the local disaster agency and the Indonesian Red Cross. Adding experts from nongovernmental organizations (NGOs) that are also actively involved in disaster management in Jakarta may help to refine the selection criteria and sub-criteria. Third, the decision-making model in this research was developed using AHP. The model can be modified by combining AHP with other approaches to improve the decision-making. Finally, the model is applicable to the preparedness stage of the disaster management cycle. It can thus be combined with the facility location model for the response stage of the cycle and the vehicle routing model, in order to become a complete decision support system for relief logistics to anticipate the frequent floods in Jakarta and to lower the response time.

\section{REFERENCES}

Ashrafzadeh, M., Rafiei, F.M., Zare, Z., 2012. The Application of Fuzzy Analytic Hierarchy Process Approach for the Selection of Warehouse Location: A Case Study. International Journal of Business and Social Science, Volume 3(4), pp. 112-125

Balcik, B., Beamon, B.B., Smilowitz, K., 2008. Last Mile Distribution in Humanitarian Relief. Journal of Intelligent Transportation Systems, Volume 12(2), pp. 51-63

BNPB, 2014. Peta Terdampak Banjir Jakarta 2014 (Map of Areas Affected by Flood in Jakarta 2014). Available online at http://geospasial.bnpb.go.id/2014/01/24/peta-terdampak-banjirjakarta-24-januari-2014-jam-06-00-wib/, Accessed on June 20, 2017

BNPB, 2017a. Statistik Bencana Indonesia 2017 (Disaster Statistics in Indonesia 2017). Available online at http://dibi.bnpb.go.id/, Accessed on September 25, 2017

BNPB, 2017b. Data dan Informasi Bencana Indonesia (Data and Information on Disasters in Indonesia). Available online http://dibi.bnpb.go.id/profil-wilayah/31/dki-jakarta, Accessed on September 25, 2017

Boonmee, C., Arimura, M., Asada, T., 2017. Facility Location Optimization Model for Emergency Humanitarian Logistics. International Journal of Disaster Risk Reduction, Volume 24, pp. 485-498

Caunhye, A.M., Nie, X., Pokharel, S., 2012. Optimization Models in Emergency Logistics: A Literature Review. Socio-Economic Planning Sciences, Volume 46(1), pp. 4-13

Caunhye, A.M., Zhang, Y., Li, M., Nie, X., 2016. A Location-routing Model for Prepositioning and Distributing Emergency Supplies. Transportation Research Part E: Logistics and Transportation Review, Volume 90, pp. 161-176

Handayani, N.U., Rinawati, D.I., Wiguna, Y.K., 2015. Model for Pre-positioning Warehouse Logistics for Disaster Eruption of Mount Merapi Sleman Yogyakarta. In: Proceedings of the Joint International Conference on Electric Vehicular Technology and Industrial, Mechanical, Electrical and Chemical Engineering (ICEVT \& IMECE), Surakarta Indonesia, 4-5 November 2015

Ko, J., 2005. Solving a Distribution Facility Location Problem using an Analytic Hierarchy Process Approach. In: Proceedings of ISAHP 2005, Honolulu - Hawaii, 8-10 July 2005

Kusumastuti, R.D., Wibowo, S.S., Insanita, R., 2013. Modeling Facility Locations for Relief Logistics in Indonesia. Book chapter in Humanitarian and Relief Logistics: Research, Case Studies and Future Trends, Operations Research/Computer Science Interfaces Series, Eds. V. Zeimpekis, S. Ichoua \& I. Minis, Springer, New York, pp. 183-206

Kusumastuti, R.D., Viverita, Husodo, Z.A., Suardi, L., Danarsari, D.N., 2014. Developing a Resilience Index towards Natural Disasters in Indonesia. International Journal of Disaster Risk Reduction, Volume 10, pp. 327-340 
Lee, S.K., Mogi, G., Kim, J.W., 2008. Multi-criteria Decision Making for Measuring Relative Efficiency of Greenhouse Gas Technologies: AHP/DEA Hybrid Model Approach. Engineering Letters, Volume 16(4), pp. 493-497

Maharjan, R., Hanaoka, S., 2017. Warehouse Location Determination for Humanitarian Relief Distribution in Nepal. Transportation Research Procedia, Volume 25, pp. 1151-1163

Moe, T.L., Pathranakul, P., 2006. An Integrated Approach to Natural Disaster Management: Public Project Management and Its Critical Success Factor. Disaster Prevention and Management, Volume 15(3), pp. 396-413

Roh, S. Jang, H., Han, C., 2013. Warehouse Location Decision Factors in Humanitarian Relief Logistics. The Asian Journal of Shipping and Logistics, Volume 29(1), pp. 103-120

Roh, S., Pettit, S., Harris, I., Beresford, A., 2015. The Pre-positioning of Warehouses at Regional and Local Levels for a Humanitarian Relief Organisation. International Journal of Production Economics, Volume 170, pp. 616-628

Saaty, T.L., 2008. Decision Making with the Analytic Hierarchy Process. International Journal of Service Sciences, Volume 1(1), pp. 83-98

Timperio, G., Hadiguna, R.A., Kamil, I., William, L., de Souza, R., 2018. Decision Support Framework for Humanitarian Relief Stockpiles: The Case of West Sumatra. TLI Paper Series: Selected Cases in Urban Logistics and Land Transport using Multi-Method Decision Analyses, Vol. 18-Jul-TF, pp. 3-13

Turgut, B.T., Tas, G., Herekoglu, A., Tozan, H., Vayvay, O., 2011. A Fuzzy AHP Based Decision Support System for Disaster Centre Location Selection and a Case Study for Istanbul. Disaster Prevention and Management: An International Journal, Volume 20(5), pp. $499-520$

UNISDR, 2009. Terminology on Disaster Risk Reduction. Available online at https://www.unisdr.org/we/inform/terminology, Accessed on June 1, 2017

UNISDR, 2017. INFORM 2017 Index. Available online at http://www.preventionweb.net/countries/idn/data. Accessed on September 25, 2017

Van Wassenhove, L., 2006. Humanitarian Aid Logistics: Supply Chain Management in High Gear. Journal of Operational Research Society, Volume 57(5), pp. 475-489 